\title{
Laajentava maitotila - kestävillä eläimillä tuotanto käyntiin
}

Jyrki Kataja, Sanna Ahonen, Mirja Riipinen

Jyväskylän ammattikorkeakoulu, Biotalousinstituutti, Tuumalantie 17, 43130 Tarvaala, jyrki.kataja@jamk.fi

Jyväskylän ammattikorkeakoulu, Biotalousinstituutti, Tuumalantie 17, 43130 Tarvaala, sanna.ahonen@jamk.fi

Jyväskylän ammattikorkeakoulu, Biotalousinstituutti, Tuumalantie 17, 43130 Tarvaala, mirja.riipinen@jamk.fi

\section{Tiivistelmä}

Yhteistyöllä kilpailukykyä maidontuotantoon -hankkeen osana tehtiin teemahaastatteluja 13 investointeja suunnittelevalla tai jo toteuttavalla maitotilalla Keski-Suomessa ja Etelä-Pohjanmaalla. Teemahaastattelujen tulosten analysoinnissa tilat ryhmiteltiin sen mukaan, mitä tekijöitä he pitivät tärkeinä eläinmäärän lisäämisen, pellonkäytön ja rakentamisprosessien kannalta. Haastattelututkimuksen tilat olivat toteuttaneet ensimmäisen investointinsa keskimäärin 6,9 vuoden kuluttua sukupolvenvaihdoksestaan. Useita investointeja tehneillä tiloilla oli vuosituhannen vaihteessa kulunut aikaa 9,25 vuotta ensimmäisen investointinsa toteutumiseen, kun taas tuotannon vakiinnuttamisvaiheessa olevat tilat olivat käyttäneet siihen 2010 luvun vaihteessa 4,8 vuotta.

Investointia suunnittelevan maitotilan tulisi aloittaa suunnittelu eläinmäärän lisäämiseksi noin kolme vuotta ennen investointia. Usein investoinnin laukaisevana tekijänä on lisääntynyt peltoala, joka mahdollistaa tuotannon laajentamisen. Eläinten hankintaan on useita vaihtoehtoja: tuotetaan itse tai ostetaan eläimiä vasikoina, siemennettyinä hiehoina tai jo lypsävinä lehminä. Kaikki vaihtoehdot ovat käyttökelpoisia, mutta toimenpiteet on suunniteltava huolellisesti. Usein sopivin vaihtoehto on yhdistelmä edellä mainituista. Huomioitavaa oli, että haastatellut maidontuottajat eivät olleet kovin tarkasti suunnitelleet eläinmäärän lisäystä. Navetan uskottiin ja toivottiin olevan mahdollisimman täynnä nopeasti. Hankkeessa toteutetun laskentamallin avulla todennettiin, että ilman toimenpiteitä uusi navetta ei täyty. Tiineytystapana voidaan käyttää tavallista siemennystä, tilasonnia, alkiota, seksattua siementä, seksattua alkiota tai liharotuista sonnia. Tutkimuksen mukaan investoineet tilat olivat sitä mieltä, että omasta kasvatuksesta sai parempaa eläinainesta. Näin eläimet tottuivat hoitajiin, paikkoihin ja olosuhteisiin vasikasta asti. Koko karjan ostamisessa oli se hyvä puoli, että samalla saatiin eri-ikäistä eläinainesta.

Peltoviljelyn toteutuksen ja sen töiden organisoinnin näkökulmasta haastattelututkimuksen tilaryhmäjakoa tärkeämmäksi tekijäksi nousi investoivien maitotilojen sijainti keskittyvän tai harvenevan maataloustuotannon alueilla. Haastattelussa mukana olleilla tiloilla oli keskimäärin 1,53 ha peltoa lypsylehmää kohti. Ensimmäistä investointiaan toteuttavat tilat olivat varautuneet kasvavan eläinmäärän rehuntuotantoon hankkimalla hallintaansa peltoa keskimäärin 3,63 ha lehmää kohti. Kaikilla haastattelututkimuksen tiloilla nähtiin peltojen hallintaan ja hankintaan liittyvät asiat yhtenä maitotilan kehittämisen perustekijänä. Lisäksi kaikki haastattelussa mukana olleet tilat pitivät peltoviljelyn tärkeimpänä tavoitteena perusrehujen tasaista, omien asettamiensa tavoitteiden mukaista laatua, johon pyritään pitämällä avaintyöprosessit omana suoritteena.

Asiasanat: maidontuotanto, karjakoko, kestävä lehmä, investointi

\section{Johdanto}

Vuosina 2010-2012 Keski-Suomessa ja Etelä-Pohjanmaalla toteutetun Kilpailukykyä maidontuotantoon -hankkeen yhteenvetona todettiin, että yrittäjän ajanpuute ja tuotannon käynnistämisen vaativuus 
johtavat tulonmenetyksiin investoivilla maitotiloilla (Turunen, Lestinen, Hölttä \& Kataja 2012). Tyyppinavetta hankkeen loppuraportissa Roininen (2014) toteaa, että navetan suunnittelu- ja rakentamisvaiheessa tehtyjä sekä rakennusteknisiä että tuotannon järjestämiseen liittyviä virheitä, on erittäin vaikea korjata maidontuotannon käynnistyttyä. Yhteistyöllä kilpailukykyä maidontuotantoon -hankkeessa haettiin tarkentavaa tietoa aikaisemmissa hankkeissa löydettyihin kehittyvien maitotilojen haasteisiin. Hankkeessa haastateltiin talvella 2014 investointia suunnittelevia ja toteuttaneita maidontuottajia KeskiSuomessa ja Etelä-Pohjanmaalla. Hanketta hallinnoi Seinäjoen ammattikorkeakoulu ja sitä toteuttivat lisäksi Jyväskylän ammattikorkeakoulu, Helsingin yliopisto sekä Osuuskunta Maitosuomi.

Jyväskylän ammattikorkeakoulun (JAMK) osuudessa paneuduttiin investoivan maitotilan eläinmäärän kasvattamiseen, rakennuttamiseen sekä työmäärän ja peltoviljelyprosessien hallintaan liittyviin kysymyksiin. Haastatteluissa ei kysytty em. tekijöiden vaikutuksista maitotilojen talouteen eikä taloudellisia vaikutuksia arvioitu myöskään laskennallisesti, koska talouteen liittyvät kysymykset kuuluivat hankkeen toisen osion tehtäviin. Tässä artikkelissa keskitytään eläinmäärän kasvattamiseen ja sivutaan osittain peltoviljelyprosessien hallintaan liittyviä kysymyksiä.

Navetan käyttöönottoajankohta määräytyy rakentamisen aikataulun mukaan. Kun tämä ajankohta on tiedossa, suunnitellaan eläinten hankinta sen mukaan. Tästä seuraa, että suuri määrä lehmien poikimisista ajoittuu samoihin aikoihin työllistäen tuottajia ja kuormittaen eläimiä uudessa ympäristössä. Mikä olisi sopiva poikimisten määrä, jotta tuotanto saadaan käyntiin niin, että eläimet, teknologia ja ihmiset saadaan toimimaan? Pitäisikö ollakin tietty aika, jolloin poikimisia ei tapahdu?

Tärkeää on tiedostaa se, että jos laajennuksen käyttöönoton aikoihin poikii paljon hiehoja, niin on todennäköistä, että ne myös joudutaan poistamaan samoina vuosina, jolloin saattaa yllättäen olla pulaa eläimistä. Jos lehmät keskimäärin poikivat 2,3 kertaa, niin se tarkoittaa, että suuri osa laajennuksen käyttöönoton aikoihin poikineista eläimistä joudutaan poistamaan toisen ja kolmannen poikimisen aikoihin. Tämän seurauksena 1-2 vuotta käyttöönoton jälkeen on varauduttava seuraavaan lehmien uudistustarpeeseen. Tuotannon vakiinnuttamiseksi eri-ikäisiä eläimiä tulisi olla riittävästi kasvamassa tai sitten olisi sovittava yhteistyökumppaneiden kanssa, että heillä olisi tarvittavat uudistuseläimet. Eläimiä ostettaessa tulisi aina olla varma ostoeläinten terveydestä. Karanteenitilat ja niiden käyttö tulisi kuulua jokaisen investoivan kotieläintilan rutiineihin. (Riipinen \& Ahonen 2014,25.)

\section{Aineistot ja menetelmät}

Hankkeen tutkimusaineisto kerättiin teemahaastatteluilla, joihin valikoitiin yhteistyössä Osuuskunta Maitosuomen ja ProAgria Etelä-Pohjanmaan edustajien kanssa Keski-Suomesta ja Etelä-Pohjanmaalta 13 maitotilaa, jotka olivat joko suunnittelemassa investointia, investoimassa parhaillaan tai investoineet viime vuosien aikana. Tiloiksi valikoitiin eri kokoluokan tiloja ja sekä lypsyasematiloja että lypsyrobottitiloja.

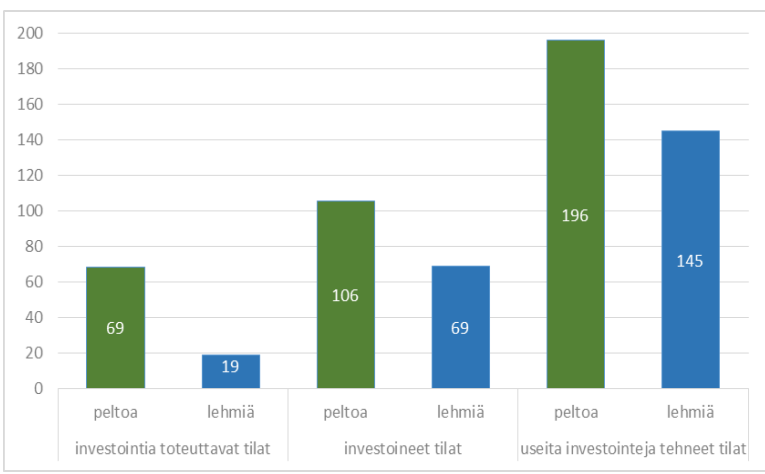

Kuvio 1. Haastattelutilojen hallinnassa olleiden peltoalojen ja lypsylehmien määrien keskiarvot vuonna 2013 (Kataja \& Autio 2014).

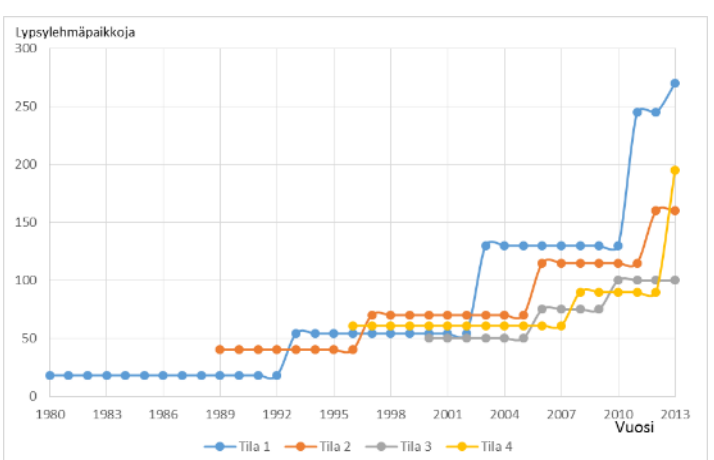

Kuvio 2. Useita investointeja tehneiden tilojen eläinpaikkojen muutokset vuosina 1980 2013 (Ahonen 2014).

Tilat jaettiin kolmeen ryhmään haastatteluhetkellä tilaa päätoimisesti viljelleiden maidontuottajien mukaan käyttäen lähtökohtana sitä olivatko he vasta suunnittelemassa ensimmäistä investointiaan vai toteuttaneet jo yhden tai useampia investointeja. Kuviossa 1 on kuvattu teemahaastatteluun osallistuneiden tilojen viljelyalojen ja lehmämäärien keskiarvot talvella 2014. 


\section{Tulokset ja tulosten tarkastelu}

Kehittyvillä maitotiloilla investoidaan säännöllisin väliajoin (Kuvio 2). Tämä tulee huomioida suunnittelussa jo alusta alkaen ja ajatella tilan tulevaisuutta pitkälle eteenpäin. Tuotannon ylösajolla tarkoitetaan sitä ajanjaksoa, joka alkaa ensimmäisistä päätöksistä, joilla tilanväki tietoisesti pyrkii vahvistamaan maidontuotantoinvestointinsa onnistumisen. Tilan toiminnan vakiinnuttaminen on tärkeää ennen seuraavan askeleen ottamista. Jos edellisestä vaiheesta on jotain tekemättä, kannattaa se saattaa ensin loppuun.

Neljän useita investointeja tehneen tilan aineisto on pieni tilastollisen tarkastelun pohjaksi, mutta vertailtaessa (Kuvio 2) 1990-luvulla tehtyjä investointeja 2000-luvun alun investointeihin, voidaan havaita haastattelutiloilla keskimäärisen investoinnin käyttöajan pituuden lyhentyneen 9,5 vuodesta 5,5 vuoteen. Pihattotilojen investoinneissa oli eläinpaikkojen lisäys ensimmäisiä investointeja tehtäessä 1990luvulla ollut keskimäärin 22 eläinpaikkaa. 2000-luvun alussa tehdyissä investoinneissa eläinpaikat olivat lisääntyneet keskimäärin 50 ja viimeisissä investoinneissa keskimääräinen lisäys oli ollut 97 eläinpaikkaa. (Kataja \& Lipsanen 2014.)

Koko teemahaastatteluaineistoa tarkasteltaessa vaikuttaisi siltä, että lypsyasematilat ovat laajentaneet toimintaansa pienemmissä paloissa kuin lypsyrobottitilat. Tämä on heidän mukaansa helpottanut projektien suunnittelua ja toteuttamista. Osa tiloista oli miettinyt tavoitteensa kymmenien vuosien päähän. Nämä maidontuottajat korostivat sitä, että vaikka nuo tavoitteet olivat tuntuneet laadintahetkellä utopistiselta, niin nyt ne olivat realismia ja onneksi oli lähdetty suunnittelemaan tuotantoa niiden mukaan. Paloittain laajennettaessa oli myös törmätty ongelmiin aiemmissa laajennuksissa rakennettujen rakennusten sijainnin kanssa, joten suunnittelussa pitää heidän mukaansa huomioida mahdolliset tulevat laajennukset niin itse rakennuksessa kuin rakennusten sijoittelussa sekä laitteistojen laajennettavuudessa. (Kataja \& Lipsanen 2014.)

Lypsyrobottitiloilla oli taas edetty suuremmilla eläinmäärien kasvuhyppäyksillä, mikä on luonnollista, koska tavoiteltavat lehmämäärät ovat lypsyrobotin optimitoiminnan eläinmäärien kerranteita. Maidontuottajat painottivat suunnittelun ja projektinhallinnan roolin merkitystä. He pitivät laajennusprojektejaan haastavina, koska laajentamisesta ei ollut juurikaan kokemusta, mutta painottivat haastatteluissaan aikaisemman työkokemuksensa ja koulutuksensa merkitystä riskienhallinnan näkökulmasta. Näillä tiloilla oli käytetty rakennuttamisessa ja itse rakentamisessa ulkopuolisia asiantuntijoita useammin kuin askelittain laajentaneilla tiloilla. (Kataja \& Lipsanen 2014.)

Hankkeessa kehitettiin laskentamalli (kuvio 3) eläinmäärän lisäämiseen lypsykarjatilalle. Laskentamalliin voidaan tilakohtaisesti laskea eri vaihtoehtoja, kuinka haluttu eläinmäärä saadaan täyteen. Suunnittelua voi tehdä kymmenen vuoden ajalle. Näin voi seurata, kuinka eläinmäärä saadaan pidettyä riittävänä myös rakentamisen jälkeen. Tiineytystapana voidaan käyttää tavallista siemennystä, tilasonnia, alkiota, seksattua siementä, seksattua alkiota tai liharotuista sonnia. (Riipinen \& Ahonen 2014.)

Laskentamalliin voi vaihtaa eri vuosille erilaisia lehmien poisto- ja vasikkakuolleisuusprosentteja sekä poikimavälin pituutta voi muuttaa. Näiden arvojen merkitys nähdään havainnollisesti taulukossa olevan kuvaajan avulla. Tavoitteena on, että tilalla tiedetään oman toiminnan seuraukset ja voidaan ryhtyä toimenpiteisiin tilanteen parantamiseksi. Keskimääräinen poikimaväli on noin 420 vuorokautta, joka tarkoittaa sitä, että vuodessa ei saada yhtä vasikkaa lehmää kohti. Tämän lisäksi vasikkakuolleisuus vähentää vasikkasaantoa ja lisäksi noin puolet syntyneistä vasikoista on lehmävasikoita eli keskimäärin lehmä tuottaa 0,37 lehmävasikkaa vuodessa. Usein investointivaiheessa ylimääräistä työtä ja stressiä on paljon eikä sen vuoksi kannata arvioida edellisiä lukuja liian hyviksi. Kuviossa 4 on esitetty ensimmäisen investointinsa toteuttaneiden teemahaastattelutilojen lypsylehmämäärät talvella 2014. Poistoja voidaan vähentää tilapäisesti navetan täyttämiseksi, mutta jossain vaiheessa poistoja on enemmän uuden navetan valmistumisen jälkeen. Lisäksi laskentamalliin on rakennettu malli, jolla voidaan laskea eläintilan tarvetta. Tämä konkretisoi hyvin sitä, kuinka paljon tilaa eläinten kasvattaminen vaatii. (Riipinen \& Ahonen 2014.)

Haastattelutilat eivät olleet kovinkaan tarkasti suunnitelleet eläinmäärän lisäystä. Navetan uskottiin ja toivottiin olevan täynnä viimeistään vuoden päästä aloituksesta. Parhaimmat pyrkivät alle puoleen vuoteen. Yksi tila aikoi täyttää navetan 3-6 kuukaudessa, tavoitteena saada 55 lypsyyn 3 kuukauden päästä aloituksesta. Yksi tila varautui vähintään 2 vuoden aikajanalla etukäteen eläinmäärän lisäykseen. Suurin osa haastatelluista oli sitä mieltä, että omasta kasvatuksesta saa parempaa eläinainesta kuin ostamalla. Sitä perusteltiin sillä, että eläimet tottuvat hoitajiin, kasvatuspaikkoihin ja olosuhteisiin heti 
alusta alkaen. Jos tilalla oli vapaata kasvatustilaa, oma kasvattaminen nähtiin hyvin järkevänä. Joissakin tapauksissa tilalla rakennettiin ensin rehusiilot ja niitä käytettiin nuoren karjan kasvatustiloina rakennuttamisen aikana. (Riipinen \& Ahonen 2014.)

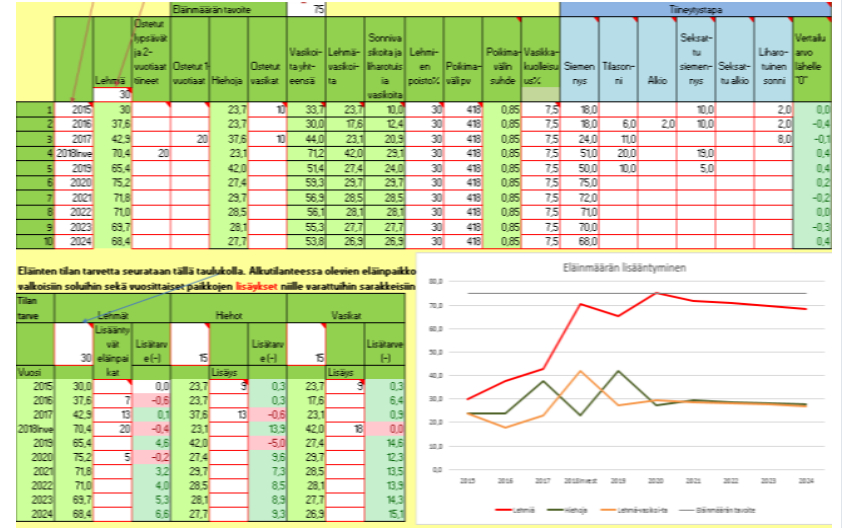

Kuvio 3. Eläinmäärän laskentamalli (Riipinen \& Ahonen 2014).

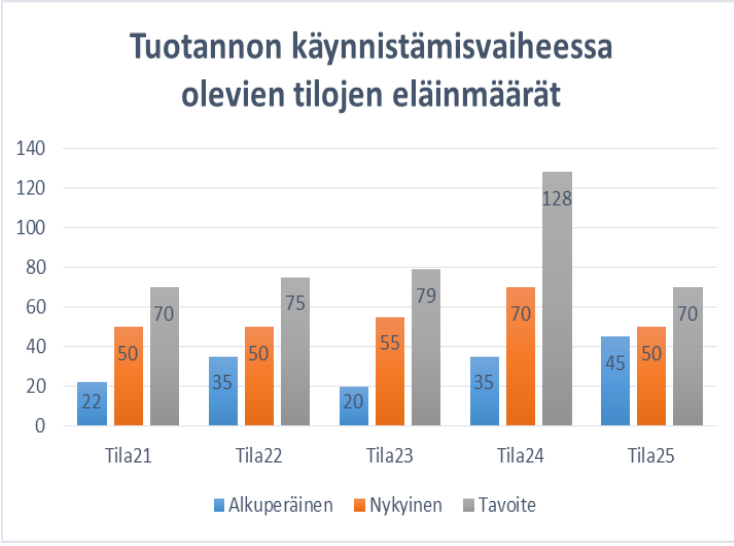

Kuvio 4. Tuotannon käynnistämisvaiheessa olleiden haastattelutilojen eläinmäärien alkuperäinen määrä, käynnistämisvaiheen määrä ja tavoitemäärä. (Riipinen \& Ahonen 2014).

Vasikkakuolleisuuden ennaltaehkäisyyn kannattaa panostaa. Lehmien tiineytysten suunniteluun käytetty työ ja kustannukset hukataan, jos vasikka syntymän jälkeen menetetään. Suunnitelmallinen toiminta, mikä olisi kaikkien tilalla työskentelevien tiedossa, parantaisi vasikoiden selviytymistä. Varhainen hyvälaatuisen ternimaidon saanti, ulkoisen tautipaineen vähentäminen ja tasaisten olosuhteiden tarjoaminen edistävät vasikoiden selviytymistä. Eläimiä siirrettäessä paikasta toiseen on hyvä muistaa suurempi tautipaine uudessa ympäristössä. Vastustuskyvyn puute aiheuttaa eniten ongelmia varsinkin pikkuvasikoissa. Vasikan vasta-aineet muodostuvat noin 6-8 viikon iässä. Jos lehmä poikii pian uuden navetan käyttöönoton jälkeen, ei sen ternimaitoon ole vielä ehtinyt muodostua uuden navetan olosuhteisiin tarvittavia vasta-aineita. Muutamalla tilalla hiehoja siirrettiin navettaan ennen navetan lopullista käyttöönottoa. Hiehojen tehtävä oli liata paikkoja ja näin muodostaa sinne bakteerikantaa ennen lypsävien siirtämistä. Navettaan muodostuu normaali bakteerikanta vasta noin vuoden jälkeen. Yhdellä tilalla oli selittämättömiä vasikoiden kuolemia, joiden loppujen lopuksi pääteltiin johtuvan siitä, ettei navetassa ollut likaa ennen eläinten siirtämistä. Navetan täytössä on hyvä huomioida se, että loppusyksystä pakkaset voivat yllättää ja silloin navetassa olisi hyvä olla jo eläimiä. Käyttöönotto voidaan tehdä myös kesäaikaan suoraan laitumelta, jolloin eläimet tottuvat liikkumaan paremmin ja käyvät keskinäisen valtataistelunsa laitumella. Uuden lypsyaseman käyttöönottoa helpottaa se, jos lehmiä kierrätetään etukäteen asemalla ennen varsinaista käyttöönottoa. Ensikoiden totutus, uusi navetta, suuret poistomäärät ja sairastelu lisäävät hoitajien henkistä kuormaa. (Riipinen \& Ahonen 2014.)

Teemahaastattelutilat olivat toteuttaneet ensimmäisen investointinsa keskimäärin 6,9 vuoden kuluttua sukupolvenvaihdoksestaan. Useita investointeja tehneillä tiloilla oli aikaa kulunut 1990 -luvun loppupuolella ja vuosituhannen vaihteessa 9,25 vuotta ensimmäisen investointinsa toteutumiseen, kun taas tuotannon käynnistämisvaiheessa olevat tilat olivat käyttäneet siihen 2010 luvun alussa 4,8 vuotta. Varsinkin nuorten maidontuottajien haastatteluissa korostui halu ja suunnitelmallisuus kehittää omaa tilaansa myös tulevilla investoinneilla, jos vain rahoituksen pystyy järjestämään kuntoon. Kaikilla tiloilla nähtiin peltojen hallintaan ja hankintaan liittyvät asiat yhtenä maitotilan kehittämisen perustekijänä. Tilat pitivät peltoviljelyn tärkeimpänä tavoitteena perusrehujen tasaista, omien asettamiensa tavoitteiden mukaista laatua, johon pyritään pitämällä avaintyöprosessit omana suoritteena. Teemahaastattelussa mukana olleilla tiloilla oli keskimäärin 1,53 ha peltoa lypsylehmää kohti. Ensimmäistä investointiaan toteuttavat tilat olivat varautuneet kasvavan eläinmäärän rehuntuotantoon hankkimalla hallintaansa peltoa keskimäärin 3,63 ha lehmää kohti (Kuvio 1). (Kataja \& Lipsanen 2014.)

Peltoviljelyn toteutuksen ja sen töiden organisoinnin näkökulmasta investointiryhmäjakoa tärkeämmäksi tekijäksi nousi investoivien maitotilojen sijainti keskittyvän tai harvenevan maataloustuotannon alueilla. Jako perustui alueellisiin eroihin pellon hankintamahdollisuuksien ja yhteistyökumppaneiden 
löytymisen välillä. Niillä alueilla, joilla on havaittavissa selkeää maataloustuotannon keskittymistä, viljelijät kertoivat, että kilpailu pellosta on todellista ja mahdollisuuksiin pitää pystyä rohkeasti tarttumaan niiden avautuessa. Toisaalta he pitivät yhteistyömahdollisuuksia toisten viljelijöiden kanssa mahdollisina ja heillä oli sekä vanhoja että uusia yhteistyöverkostoja käytössään. Harvenevan maataloustuotannon alueilla peltoa sai helposti vuokrattua tai yhteistyösopimuksilla käyttöönsä, mutta koneyhteistyölle ei löytynyt kovin helposti sopivia kumppaneita. Laajemmin esiintyessään nämä tekijät voivat kohdentaa kustannuksia eri alueilla eri tavalla; joko korkeisiin peltokustannuksiin ja alhaisempiin konekustannuksiin tai alhaisempiin peltokustannuksiin ja korkeampiin konekustannuksiin. (Kataja \& Autio 2014.)

\section{Johtopäätökset}

Useita investointeja tehneiden tilojen eläinpaikkojen kehitys kuviossa 1 kuvaa hyvin sitä, miten maidontuotannon nykyisessä tuotantorakenteen muutoksessa investoinnit kotieläinrakennuksiin ja niiden toimintoihin seuraavat hyvin tiiviissä, muutaman vuoden syklissä toisiaan. Maidontuottajat eivät enää rakenna yhtä tuotantorakennusta sukupolvenvaihdoksien välillä, vaan jatkuva, asteittainen tuotannon kehittäminen ja siihen liittyvät mittavat rakennusinvestoinnit, näyttävät tulevaisuudessa vain nopeutuvalla tahdilla seuraavan toisiaan. Rakennuttamisella on kuitenkin tietyt vaiheensa - tarveselvityksistä suunnittelun kautta varsinaiseen rakentamiseen ja uuden tuotantotilan käyttöönottoon. Kun maidontuotannon viime vuosien kehityksen pohjalta tarkastelee navetoiden rakentamista, on aika kääntää perinteinen rakennuttamisen ja sen osa-alueiden kuvaus suoraviivaisesta projektikuvauksesta jatkuvan rakennuttamisen spiraaliksi, jossa seuraava tuotannon kehitysvaihe toteutusratkaisuineen rakentuu edellisten vaiheiden perustuksille.

Lehmän olisi hyvä poikia 6 viikkoa ennen uuteen navettaan siirtymistä. Tällöin syntyneellä vasikalla on käynnistynyt oma vasta-ainetuotanto ja sopeutuminen uusiin tiloihin tapahtuu kivuttomammin. Toinen vaihtoehto on siirtää hiehot navettaan jo ennen navetan käyttöönottoa. Tällöin ne ovat likaamassa paikkoja jo etukäteen ja muodostamassa ternimaitoon tarvittavia vasta-aineita.

Uuden navetan käyttöönottovaiheessa on yleensä paljon hiehoja, joka tarkoittaa sitä, että karja on hyvin samanikäistä. Tämä tulee huomioida siinä, että poistojakin tulee olemaan paljon samaan aikaan, jos ajatellaan keskimääräistä lehmien poikimakertaa $(2,3)$. Lehmien poistomäärät voivat vaihdella vuosittain paljonkin ja tähän tulee siis varautua jo investoinnin suunnitteluvaiheessa. Investoineella tilalla ei ole varaa pitää navetassa tyhjiä lehmäpaikkoja muutaman vuoden päästä investoinnista, jolloin lainanlyhennykset pyörivät jo normaalisti.

Yleensä navetan käyttöönottoajankohta määräytyy rakentamisen aikataulun mukaan. Kun tämä ajankohta on tiedossa, suunnitellaan eläinten hankinta sen mukaan. Pitäisikö tämä kääntää toisin päin eläinmäärän kasvattamisen vaiheet määräävät eri rakennusvaiheiden valmistumisen aikataulutuksen ja navettainvestoinnilla on useita vaiheittaisia käyttöönottoajankohtia. Eläinten lukumäärästä huolehtiminen ei pääty investoinnin valmistumiseen, vaan suunnitelmien tulisi jatkua vuosia eteenpäin. Jos investoinnin valmistumisen aikoihin poikii paljon hiehoja, niin niiden poistot ajoittuvat myös samoihin vuosiin. Viime vuosina Suomessa on investoitu maidontuotantoon ja navetoiden kokoluokka on kasvussa. Tuhannet lehmät, hiehot ja vasikat ovat vaihtaneet karjasta toiseen. Hyvä suunnittelu ja ennakointi takaavat jatkossakin terveet eläimet ja kannattavan maidontuotannon.

\section{Kirjallisuus}

Kataja, J. \& Autio, A. 2014. Pellonkäytön prosessit. Teoksessa: Ahonen, S. (toim). Laajentava maitotila - tavoitteista tuloksiin. Yhteistyöllä kilpailukykyä maidontuotantoon. Jyväskylän ammattikorkeakoulun julkaisuja 188. 27-34.

Kataja, J. \& Lipsanen, H. 2014. Rakentamisprosessi. Teoksessa: Ahonen, S. (toim). Laajentava maitotila - tavoitteista tuloksiin. Yhteistyöllä kilpailukykyä maidontuotantoon. Jyväskylän ammattikorkeakoulun julkaisuja 188. 35-39.

Riipinen, M. \& Ahonen, S. 2014. Eläinmäärän suunnitelmallinen lisääminen. Teoksessa: Ahonen, S. (toim). Laajentava maitotila - tavoitteista tuloksiin. Yhteistyöllä kilpailukykyä maidontuotantoon. Jyväskylän ammattikorkeakoulun julkaisuja 188. 14-26. 
Roininen, A, 2014. Tyyppinavetta-hankkeen loppuraportti. Viitattu 11.11.2015. http://www.mtk.fi/maatalous/tyyppinavettahanke/tyyppinavetta_loppuraportti/fi-FI/ tyyppinavetta_lop-puraportti/_files/91800488672757775/default/Laajaraportti.pdf.

Turunen, M., Lestinen, T., Hölttä, S. \& Kataja, J. 2012 Tuotannon ylösajo. Teoksessa: Nissinen, K. (toim). Maitotilan prosessien kehittäminen; Teknologisia ratkaisuja, rakennuttaminen ja tuotannon ylösajo, Seinäjoen ammattikorkeakoulun julkaisusarja B, Raportteja ja selvityksiä, 106-124. 